\title{
Shaping the ESP curriculum of an english for PhD students program: a colombian case study of questionnaire research *
}

\author{
Diseño de un currículo de ingles para propósitos \\ específicos dirigido a un programa de inglés para \\ doctorados: estudio de caso utilizando encuestas
}

Received: 1 - Apr - 12 / Accepted: 5 - Oct -12

Gerriet Janssen

Univeristy of Hawai'i Mãnoa

Honolulu - USA

E-mail: gjanssen@hawaii.edu

Ricardo Nausa

Universidad de los Andes

Bogotá - Colombia

E-mail: ra.nausa20@uniandes.edu.co

Carlos Rico**

Universidad de los Andes

Bogotá - Colombia

E-mail:carlitos1009@yahoo.com

\begin{abstract}
This report presents the findings from an EAP curriculum development project directed towards PhD students at Colombian university. An analysis of this stakeholder group's learning needs was conducted through questionnaire research, focusing on (a) describing students' situated contexts and interests and (b) obtaining data contributing towards future program development. Measures of central tendency, dispersion, and internal consistency for each section of the questionnaire are reported. Key results include these students' strong interest in EAP programming, their language needs and experience regarding their intellectual production, and their perceived importance of different language sub-skills in both the local and international contexts. The results highlight the importance of continued evaluation cycles and the important role EAP coursework has for $\mathrm{PhD}$ students today.
\end{abstract}

Key words: questionnaire research, curriculum development, English for Academic Purposes (EAP), needs analysis, Ph D students, statistical analysis.

\section{Resumen}

Este informe presenta los resultados de un proyecto curricular encaminado a la creación de un programa de EAP para los estudiantes doctorandos de una universidad colombiana. Un nuevo análisis de necesidades de aprendizaje de estos estudiantes se llevó a cabo, que se centró en (a) el contexto situacional e intereses lingüísticos de estos estudiantes y (b) los datos que contribuyeran al desarrollo futuro del programa. Se llevaron a cabo los indicadores de tendencia central, medidas de dispersión y la consistencia interna para cada sección del cuestionario. Los resultados le brindaron al programa universitaria información acerca del interés de los estudiantes en el EAP, sus necesidades lingüísticas y su experiencia con respecto a la divulgación de la producción intelectual, su experiencia y tiempo dedicado como usuarios de lengua, y la importancia percibida de las sub-destrezas lingüísticas en los contextos locales e internacionales. Los resultados del estudio resaltaron la importancia de ciclos continuos de realimentación y la importancia de las habilidades de EAP para los estudiantes de doctorado hoy en día. 
Palabras claves: investigación con encuestas, desarrollo curricular, inglés para propósitos académicos, análisis de necesidades, estudiantes de doctorado, análisis estadísticos

\section{Résumé}

Ce rapport présente les résultats d'un projet d'études orienté à la création d'un programme d'EAP pour les étudiants de doctorat d'une université colombienne. Une nouvelle analyse des besoins d'apprentissage de ces étudiants a été effectuée. Cette analyse s'est centrée : a) dans le contexte de la situation et des intérêts linguistiques de ces étudiants ; b) les données qui pouvaient contribuer au développement future du programme. Pour chaque section du questionnaire, les indicateurs de tendance centrale et de dispersion et la cohérence interne ont été établis. Ses résultats ont fourni au programme universitaire des informations sur l'intérêt des étudiants dans l'EAP, leurs besoins linguistiques et leur expérience concernant la diffusion de la production intellectuelle, leur expérience et le temps investi comme des usagers de langage, ainsi que la perception de l'importance des sous-compétences linguistiques dans les contextes nationaux et internationaux. Les résultats de l'enquête ont mis en relief l'importance des cycles permanents de réalimentation et des compétences d'EAP pour les étudiants de doctorat aujourd'hui.

Mots clés: recherche au moyen d'enquêtes, développement curriculaire, anglais pour buts académiques, analyse de besoins, étudiants de doctorat, analyse statistique.

\section{Resumo}

Este relatório apresenta os resultados de um projeto curricular encaminhado à criação de um programa de EAP para os estudantes doutorandos de uma universidade colombiana. Uma nova análise de necessidades de aprendizagem destes estudantes realizou-se, que se enfocou no (a) contexto situacional e interesses linguísticos destes estudantes e (b) os dados que contribuíram ao desenvolvimento futuro do programa. Realizaram-se os indicadores de tendência central, medidas de dispersão e a consistência interna para cada seção do questionário. Os resultados ofereceram ao programa universitário informação sobre o interesse dos estudantes no EAP, suas necessidades linguísticas e sua experiência com relação à divulgação da produção intelectual, sua experiência e tempo dedicado como usuários de língua, e a importância percebida das subdestrezas linguísticas nos contextos locais e internacionais. Os resultados do estudo ressaltaram a importância de ciclos contínuos de realimentação e a importância das habilidades de EAP para os estudantes de doutorado hoje em dia.

Palavras chaves: pesquisa com enquetes, desenvolvimento curricular, inglês para propósitos acadêmicos, análise de necessidades, estudantes de doutorado, análise estatísticas.

* This article reports some findings of the Project: Programa de Inglés Para Doctorados (IPD), Universidad de los Andes. Carried out between January 2009 and January 2012. 


\section{Introduction}

\section{A Colombian EAP Program}

In the past two decades, the discussion of bilingualism in Colombia has gained an important, yet contested, ground. Growing interest in second language use is widely attributed to the forces of globalization, market economies, and the allpervasive Hollywood entertainment industry; evidence of diverse and dynamic linguistic landscapes can be seen in many aspects of daily life in Colombia (cf. Cubides, Florez, Guarín, Murcia, E Janssen, 2011; Fernández $\mathcal{E}$ Janssen, 2011). In the legislative arena, two important governmental decrees concerning SpanishEnglish bilingualism have been passed, (i.e., the National Education Law, Law 115 of 1994, and Programa Nacional de Bilingüismo 2004-2019 [the National Program for Bilingualism 20042019, popularly known as Colombia Bilingüe]). Contributions to the discussion of this situation and results of these laws within the Colombian educational context have been made by many (cf. Cárdenas, 2006; Clavijo, 2004; González, 2008; González, 2009; López \& Janssen, 2010; Ordóñez, 2011; Truscott de Mejía, 2006; Truscutt de Mejía, Ordóñez, E Fonseca, 2006; Truscott de Mejía, López Mendoza, \& Peña Dix, 2011; Usme, 2009).

Situated within this textured context is the Universidad de los Andes, a private research university, whose development goals include many specific foci concerning the university's presence within the international sector:

"1.6 Facilitate the internationalization of its programs"1 (Universidad de los Andes, 2011, p. 8); "2.7 Promote the effective movement of its professors in regional and international spheres"2 (p. 9); "4.3 Promote the development of research in conjunction with internationally recognized partner universities"3 (p. 11); "9.3 Maintain an active national and international presence through publications, seminars, and events that promote the critique and debate of themes of public interest"4 ( $p$. 12).

At this university, many departmentsespecially at the $\mathrm{PhD}$ level of programminginclude international exchanges as a requirement for graduation. While these authors are wary of concluding that "international" is synonymous with "English," nevertheless, several highenrollment, high-visibility departments at this university approached the researchers' department petitioning the development of the research project Proyecto IPD (IPD: Inglés Para Doctorados ${ }^{5}$ ). This research project would result in the creation of an English-language programPrograma IPD 6 a program designed for a $\mathrm{PhD}$ student population, whose coursework would be centered on developing student strategies for success in the English language domains of writing for publication and speaking for professional presentations. (N.B. Henceforth, specific references related to the research project will be called Proyecto IPD, while those concerning the curricular programming that resulted from the project are called Programa IPD). Proyecto IPD was developed following Brown (1995), Dubin E Olshtain (1986), Nunan (1988), and Richards (2001); the basic workflow inspired by these authors for this initial investigation-and the tools used to develop each stage-are listed below:

(1) a. Analysis of perceived needs: language and situational needs

b. Interviews with department directors throughout the university

(2) Questionnaire research, using surveymonkey. com

(3) Analysis of linguistic proficiencies, using an in-house proficiency exam

(4) Analysis of the context of the students, and 
of the departments in the university

(5) Definition of broad program goals

(6) Definition of the program philosophy, ideologies, methodologies, foci

(7) Determination of general and specific course goals throughout the four levels of the program

(8) Selection and organization of program content and order

(9) Implementation of the program

(10)Evaluation of the program by peers, students, and other stakeholders, such that adjustments can be made

The needs analysis component of this program development process-steps $1 \mathrm{a}$ and $1 \mathrm{~b}$-included survey data collected in interviews with different $\mathrm{PhD}$ program directors and questionnaires directed towards $\mathrm{PhD}$ candidates and current PhD students. Data from the questionnaire instrument $(n=80)$ administered in 2009 were used to guide program development and inform the Proyecto IPD final report (Janssen, Ángel, \& Nausa, 2011), and there were three pivotal findings. First, the concept of noticeable decreases in English language studies as informants advanced in their educational development ${ }^{7}$ was used to predict that there would be gaps in the questionnaire informants' academic English formation, justifying an English for Academic Purposes (EAP)-style class framework. Next, inconformity between university program directors and $\mathrm{PhD}$ students in terms of the concept of which general language abilities are viewed as being most important was used to justify a holistic syllabus framework instead of separate classes for different language skills. Finally, wide consensus on the concept of the importance of different academic sub-skills was used to further justify the holistic EAP academic framework of Programa IPD. As a conclusion, the 2009 questionnaire succeeded in gathering important data that meaningfully shaped the way Programa
IPD developed; nevertheless, coordinators and directors within Dpto-LESC and Programa IPD knew that the program must continue to gather survey research data to ensure the good fit of its newly created curricular programming with the emerging needs of its student population.

\section{Programa IPD Program Feedback Mechanisms}

Again following Brown (1995), Dubin $\mathcal{E}$ Olshtain (1986), Nunan (1988), and Richards (2001), Proyecto IPD strove to include in its long-term implementation of its initial curriculum development process different evaluation procedures (see step 9 in the above list). These procedures were centered on the three following recommendations:

- The collection of external and internal validity evidence. This is to support the construction of a placement exam validity argument (Messick, 1995).

- The development of detailed student grade reports (per class), a tracking system maintained by the IPD coordinator to monitor student progress. This is to check for placement exam accuracy, to assure program function, and to monitor student development.

- The solicitation of student feedback about the program on pre-placement questionnaires (part of the curriculum development process), on post-semester questionnaires, and in postsemester focus groups considering the success of each course's student learning outcomes (SLOs). These feedback mechanisms are in place to ensure that Programa IPD perceives student needs clearly and responds to them appropriately.

This survey research project, then, contributes towards developing the above agenda by considering the last of these processes-the continuous solitication of student feedback on pre-program questionnaires as part of a 
larger feedback cycle-and poses the following questions:

- What do survey research data reveal about PhD students' situated contexts and their English language learning interests?

- How do these survey research data contribute to future program development? ${ }^{8}$

By responding to these questions, Programa IPD stakeholders will continue to gather both quantitative and qualitative data documenting incoming $\mathrm{PhD}$ students' perceptions of their academic environment. This can be used to inform director-level personnel of these situations. Furthermore, the questionnaire data analysis will hopefully and newly affirm for program and other university stakeholders the perceived importance of the different academic sub-skills that this program develops, in addition to the findings from new question prompts. This current information may be useful when negotiating still undecided details of this new program within its high-stakes environment, when developing similar-type programs or survey research projects in the future, and above all else while monitoring the state of Programa IPD through the systematic and focused gathering of stakeholder opinion.

\section{Methods}

This survey research project used a questionnaire first used in 2009, a 12-page, 173 item $^{9}$ Spanish-language instrument developed on the surveymonkey.com platform. This first questionnaire-henceforth referred to as the 2009 questionnaire-was designed following one developed by Gravatt, Richards, $\mathcal{E}$ Lewis (1997, as cited in Richards, 2001, pp. 80-86) because of the perceived similarities between these authors' university EAP setting for nonEnglish background students and the IPD setting: a tertiary EAP English program for non-English background students. Not only did the similarity of the contexts have an exciting face validity when developing the 2009 survey instrument, it was also believed that a questionnaire based on Gravatt, Richards, $\varepsilon$ Lewis's would be useful at later stages of curriculum development for monitoring student interest in the program. This was because this questionnaire template asked informants to describe or rate many factors of high interest to curriculum developers. For instance, the two sections the importance of different general English language abilities [reading, writing, speaking, and listening] for success during / after their PhD program was used to establish the degree of relevance of different general English language abilities for $\mathrm{PhD}$ informants; number of hours spent per week studying English/in English throughout primary, secondary, and university level education was used to help document informant development within the target language. Items concerning the importance of different sub-skills (eg., starting a discussion, understanding verbal instructions, understanding unknown vocabulary) were used to affirm stakeholder interest in Programa IPD course sub-skills.

As part of this current (2011) feedback project for Programa IPD, the 2009 questionnaire was extensively revised (only 11 of the original 173 items - 6.36\% - remaining identically the same) with the result of a 12-page, 180-item, Spanish-language questionnaire instrument. To revise the questionnaire, suggestions from Brown's book section "Guidelines for Writing Good Survey Questions” (2001, pp. 40-54) were considered by the authors: 71 items (41.04\%) from the 2009 questionnaire that were unused in the 2009 data analysis were eliminated (p. 54); 16 items $(9.25 \%)$ that were logically flawed ${ }^{10}$ (p. 49), 25 items (14.45\%) that were either prestige questions ${ }^{11}$ (p. 50) or questions that "led the witness" (p. 51) were reformulated to maintain a broader neutrality; almost all other questions were rephrased for greater clarity (p. 49). Seventy-six 
new items were added for themes warranting exploration-those themes emerging from previous focus groups with course graduates-were written or expanded from existing question stems.

The revised questionnaire was reviewed by these authors in real-time using Google Docs while simultaneously messaging each other using Google Docs chat or Facebook chat, as one author was working remotely from his $\mathrm{PhD}$ program in Hawai'i while the other two were on-site in Colombia. The final draft version of the 2011 questionnaire was reviewed by several professors in Colombia to eliminate any grammatical, semantic, or technical problems before its implementation. The complete questionnaire is described below in Table 1; the specific questions for each subsection of the questionnaire are included as part of the statistical analyses in the different appendices.

Table 1. IPD Questionnaire Overview

\begin{tabular}{|c|c|c|}
\hline$\S$ & Questionnaire section construct & Question number, types \\
\hline$\S 1$ & Project description, authorization of data use for research purposes & 1 yes/no \\
\hline$\S 2$ & Personal biodata & $\begin{array}{l}11 \text { items: } 5 \text { pull-down menu multiple-choice items; } 6 \text { open-ended } \\
\text { items }\end{array}$ \\
\hline$\S 3$ & Academic biodata & $\begin{array}{l}31 \text { items: } 7 \text { pull-down menu multiple-choice items; } 24 \text { open-ended } \\
\text { items }\end{array}$ \\
\hline$\S 4$ & Time uses & $\begin{array}{l}19 \text { items: } 9 \text { pull-down menu multiple-choice items; } 10 \text { open- } \\
\text { ended items soliciting further commentary. }\end{array}$ \\
\hline$\S 5.1$ & Historical English language use in different domains & $\begin{array}{l}18 \text { items: } 17 \text { 5-point Likert-scale items, } 1 \text { open-ended item solicit- } \\
\text { ing further commentary }\end{array}$ \\
\hline$\$ 5.2$ & Time investment in English language study during schooling & $\begin{array}{l}5 \text { items: } 4 \text { 5-point Likert-scale items, } 1 \text { open-ended item soliciting } \\
\text { further commentary }\end{array}$ \\
\hline$\$ 5.3$ & Reported skill level, different general English language abilities & $\begin{array}{l}8 \text { items: } 7 \text { 5-point Likert-scale items, } 1 \text { open-ended item soliciting } \\
\text { further commentary }\end{array}$ \\
\hline$\$ 5.4$ & Difficulty, different general English language abilities & $\begin{array}{l}8 \text { items: } 75 \text {-point Likert-scale items, } 1 \text { open-ended item soliciting } \\
\text { further commentary }\end{array}$ \\
\hline$\$ 6.1$ & $\begin{array}{l}\text { Relevance of different general English language abilities for suc- } \\
\text { cess during PhD }\end{array}$ & $\begin{array}{l}10 \text { items: } 9 \text { 5-point Likert-scale items, } 1 \text { open-ended item solicit- } \\
\text { ing additional commentary }\end{array}$ \\
\hline$\$ 6.2$ & $\begin{array}{l}\text { Relevance of different general English language abilities for suc- } \\
\text { cess after PhD }\end{array}$ & $\begin{array}{l}10 \text { items: } 95 \text {-point Likert-scale items, } 1 \text { open-ended item solicit- } \\
\text { ing additional commentary }\end{array}$ \\
\hline$\S 6.3$ & Dis/ agreement with statements about Programa IPD & $\begin{array}{l}6 \text { items: } 5 \text { 5-point Likert-scale items, } 1 \text { open-ended item soliciting } \\
\text { additional commentary }\end{array}$ \\
\hline$\S 7$ & Programa IPD speaking sub-skills & $\begin{array}{l}25 \text { items: } 24 \text { 5-point Likert-scale items; } 1 \text { open-ended item solicit- } \\
\text { ing additional commentary }\end{array}$ \\
\hline$\S 8$ & Programa IPD listening sub-skills & $\begin{array}{l}17 \text { items: } 16 \text { 5-point Likert-scale items; 1open-ended item, solicit- } \\
\text { ing additional commentary. }\end{array}$ \\
\hline$\S 9$ & Programa IPD writing sub-skills & $\begin{array}{l}27 \text { items: } 26 \text { 5-point Likert-scale items; } 1 \text { open-ended item, solicit- } \\
\text { ing additional commentary. }\end{array}$ \\
\hline$\$ 10$ & Programa IPD reading sub-skills & $\begin{array}{l}17 \text { items: } 16 \text { 5-point Likert-scale items; } 1 \text { open-ended item, solicit- } \\
\text { ing additional commentary. }\end{array}$ \\
\hline$\S 11$ & Programa IPD vocabulary and grammar sub-skills & $\begin{array}{l}6 \text { items: } 5 \text { 5-point Likert-scale items; } 1 \text { open-ended item, soliciting } \\
\text { additional commentary. }\end{array}$ \\
\hline$\S 12$ & Thank you and final comments & 1 open-ended item, soliciting additional commentary. \\
\hline
\end{tabular}




\section{Procedures}

The 2011 questionnaire was implemented on October 22, 2011 as part of the admissions testing and interview protocol at Universidad de los Andes. The questionnaire was the last part of the IPD placement exam and was optional. Nevertheless, of the 96 people who took the exam on this date, 93 responded to the questionnaire. One potential informant chose not to give permission to use their results, so only 92 results could be analyzed, giving a response rate of 95.83\% for the 2011 questionnaire administration.

\section{Analyses}

Though the 2011 questionnaire gathered qualitative and quantitative data, this project only reports quantitative results, with an eye towards expanding quantitative studies in the Colombian EFL context. First, descriptive statistics looking reporting indicators of central tendency-"the typical or most representative characteristics of a set of scores" (Hudson, (in press) p. 4-7)—were calculated for each section of the questionnaire, using Excel. The measures reported in this study include the mean, median, and mode. Following Iwai et al. (1999), the items in each questionnaire subsection were organized according to their means in a decreasing order. This methodology effectively ranks the results of each questionnaire subsection within the different categories from the highest mean (i.e. "most important concept") to lowest mean (i.e. "least important"). Medians (the middle number of a data set) and modes (the most common response)-when different from the arithmetic mean-have been reported as they help describe when the distribution of the data points is skewed towards one end of the spectrum of the possible answers (Brown, 2001, pp. 121-122). Measures of dispersion have also been reported as they "describe the variability around a central value" (Hudson,
2011, 4-8, 4-9). Thus, this paper reports the minimum, maximum, and range of the different Likert-scale items. In addition, it also reports the standard deviation "perhaps the single most useful statistic for indicating dispersion in a set of scores... [which is] the average amount the scores vary from the mean for each questionnaire item" (Hudson, (in press) pp. 4-9). By calculating these descriptive statistics, and most importantly, by listing these results in descending mean order, one can see the larger picture that these distinct data points collectively construct about what the $\mathrm{PhD}$ student population thinks is important in their EAP studies.

Finally, Cronbach's alpha-measuring the data's internal consistency-was calculated using the free statistics software Systat; this measure has been reported for the items within each section of the questionnaire. Cronbach's alpha, when approaching 1.00 for the group of data being studied, signals strong internal consistency within a data set. In this case, a large Cronbach's alpha for a set of items within a questionnaire section indicates that the questionnaire section has a strong internal consistency with itself. Accordingly, this statistic also supports arguments for the questionnaire's construct validity.

\section{Results}

The complete descriptive statistics have been provided for the entire questionnaire in Appendix A, Tables 2-13. These results consistently confirm PhD student interest in EAP studies that target both the Colombian context and the international context. Following are what these researchers believe are the most important of all the results shown in these different questionnaire sections.

The biodata that were gathered in the 2011 questionnaire are shown in Appendix A, Table 2. Most directly relevant to Programa IPD is that 
most informants have finished their MA studies in the past two years (2009), finishing their BA approximately in 2005. Assuming a two-year master's program, these results indicate that the average informant has had approximately four years of "other" experience before continuing on with their doctorate level education. This suggests a more developed level of personal maturity than typically found in undergraduate students. Also of importance to Programa IPD program developers is the number of publications and presentations informants report having completed. The means for these data points are 3.35 publications and 4.76 presentations, yet it is important to note that the medians and modes are lower than the means: the medians being 2.5 publications and 3 presentations, the modes being 1 publication, and 2 presentations. This indicates that there are some statistical outliers that have published and presented a great deal, whereas the typical incoming $\mathrm{PhD}$ candidate has done much less. The implications of these candidates' maturity and publication/ presentation history will be further examined in the discussion section.

In terms of their usage of time, these informants reveal that they are busy professionals, working and studying on average approximately 54 hours per week, as is shown in Table 3, Appendix A. Of particular importance to Programa IPD is the result that informants would ideally dedicate approximately 6 hours per week on average to English studies, realistically hoping to dedicate $31 / 3$ hours per week on average to these studies. This is inconsistent with the amount of time that IPD programming requires of its students: 7.5 hours per week (plus another 3-6 hours per week in homework) for IPD 1, 2, and 3; 4.5 hours per week (plus another 3 hours per week in homework) for IPD 4 (Janssen, Ángel, E Nausa, 2011). This important difference in perspectives about time use will also be discussed in the conclusion section.
Finally, informants consistently rated as being "more important" language subskills whose use is to be developed in the international context (e.g., giving a presentation in an English speaking context) than those to be developed within the Colombian context (e.g., giving a presentation in English in Colombia). Furthermore, all specific academic subskills were considered very important (e.g., understanding a scholarly publication), while distractor-type items added to ensure informant attention to the survey (e.g., reading fiction) were rated less favorably. These findings, shown in Tables 9-13, Appendix A, indicates that Programa IPD's different student learning outcomes should focus specifically on skills for the international context in addition to in the Colombian context. Further implications of this will be considered in the discussion section.

In terms of Cronbach's alpha and its indications concerning the construct validity of this questionnaire instrument, the very high Cronbach's alpha calculations for each section of the questionnaire indicate that informants respond to the different items within each sub-section in a highly consistent fashion. This consistency also serves to show that items may be omitted from each section without jeopardizing the general construct being developed by the section.

\section{Discussion}

The 2011 Programa IPD questionnaire was able to shed light on valuable information for different stakeholders in Programa IPD. These global trends should continue to be monitored to ensure that the Programa IPD is able to respond to changes in demographics or perceptions about the role of English in the life of a PhD student.

First, when observing the age of these candidates and realizing that the majority have had at least four years of life experience beyond undergraduate education, course 
instructors should realize that this student population is markedly different from typical undergraduates: it can be said that these students are more mature and have a sharpened focus on what is academically interesting to them, something that is also anecdotally believed by IPD course instructors about these students. These researchers believe that this greater maturity warrants a program philosophy that has as one of its pillars respect for students as adult colleagues.

Despite their greater life experience than typical undergraduate students, it is interesting to note that most students report little experience in these academic genres, as evidenced by low numbers of informant publications and presentations. Since academic publication and presentation skills are at the heart of Programa IPD's coursework objectives, this lack of skills in incoming students indicates that the program is filling the niche it was originally called to address and reaffirms that these foci should continue to be among the core foci that Programa IPD coursework should have. Nevertheless, instructors should not assume no experience in these genres, but rather that there is "room for growth." Furthermore, instructors should also assume that some students will have a good deal of publication and presentation experience, which can help enrich the class development of these themes. It could also be a possibility that Programa $I P D$ directorial personnel consider extensive publication and presentation experience-in addition to placement test results-as part of a variety of factors that determine exemption from IPD coursework. Programa IPD developers should not be satisfied with the results of this second survey, but should continue to monitor the publication and presentation experience of this student population, to assure that the program adequately responds to changing student needs.

The second important result concerned a difference in student and program developer expectations for the time investment require for the completion of Programa IPD, a finding that should be contemplated by Dpto-LESC and Programa IPD directors and instructors alike. Large differences in expectations in something as valuable as time use suggests that there could be an issue that needs addressing, especially as this trend has also been evidenced by a focus group in 2010 and two led in 2011. Since time is such a sensitive issue in the twenty-first century, globalized context, left unheeded, this issue could prove deleterious to the overall long-term success of Programa IPD. Instructors must ensure that their class plans treat each moment as an important one; homework tasks equally must be well-developed and of clear value to these busy students. Furthermore, instructors and staff should engage in efforts to remind students that language learning is not an easy process, but rather one which requires an extensive investment of time. Further survey research could also address whether different stakeholders believe this incongruity should be resolved through the reduction of coursework or through the recognition by their home departments of the demands that making gains in language proficiency will require a certain investment of time. As with the prior results, these survey results should not be thought of as definitive; instead, simple feedback cycles should be developed with the student population, to ensure that all stakeholder needs are being met within the language program.

In terms of the importance of different language skills, the data from the 2011 questionnaire reconfirms the data gathered in 2009: once again, the development of EAP English language skills is highly important for PhD students in this particular university context, much more so than other non-academic language skills. However, the degree to which informants were able to distinguish between these different specific sub-skills is not known; indeed, it is quite 
possible that anything "academic sounding" would necessarily be important to them as a $\mathrm{PhD}$ candidate, while less academic skills (e.g., reading poetry aloud, socializing with peers in English in Colombia) are not as important. Preliminary factor analysis of the entire survey bears this out: as an example, the entirety of the different academic writing subskills correlates very closely to one factor (i.e., there is presumably one underlying theoretical construct operating in this section), while the entirety of the academic reading subskills correlates to a second, different factor (i.e., there is presumably a second, underlying theoretical construct operating in this second section). This implies that future efforts to document the importance students give to different course goals or create feedback cycles between students and Programa IPD directors may be done with a survey instrument that is much more concise.

As part of this result, there were also interesting differences in the importance concerning certain language skills being used in the Colombian context versus these same skills used in an international context. The consistent importance given to the international context indicates that tasks considering different interactive general language abilities (speaking and listening) should be contextualized for the international context, something which will be a new addition to the curriculum. Nevertheless, using these EAP skills in the Colombian context should not be forgotten or omitted from future curricular developments. Again, it bears repeating that only through a development of a deliberate evaluative feedback cycle can program developers hope to refine their understanding of what is important to students and the ways in which this is important.

Finally, due to the extremely high values of the Cronbach's alpha that were calculated for each questionnaire subsection-in addition to a preliminary factor analysis indicating that informants were responding to the separate academic subskills as one broader construct, curriculum designers should consider omitting a large portion of the questions that were asked within each subsection. This would support Dörnyei \& Taguchi's maximum suggested questionnaire length of "four to six pages" (2010, p. 12, as cited in Davis, 2010), something that was broadly ignored by these researchers in hopes of gaining a rich description of the informants' contexts. Having a much briefer questionnaire would foster the development of a deliberate feedback cycle that is informative, but also efficient to complete and interpret.

One last area that could be considered in future editions of the survey would also consider what the students need from the instructors in this program. While survey questions to date have looked closely at student needs for their own lives or for the IPD coursework that they are about to take, no mention has been made of their conceptualization of the instructors who actually facilitate these courses. Accordingly, it would be highly informative to begin to include such questions in the next edition of the survey, such that Programa IPD not stagnate in the apathy of the known, but rather strive forward to serve and otherwise interact with its adult colleague participants in the most useful way that is possible.

\section{References}

Brown, J.D. (1995). The elements of language curriculum: A systematic approach. Boston, MA: Heinle ELT.

Cárdenas, M. L. (2006). Bilingual Colombia: Are we ready for it? What is needed? Paper presented at $19^{\text {th }}$ Annual EA Education Conference 2006. Retrieved from http://www.englishaustralia.com.au/ ea_conference2006/proceedings/pdf/Cardenas.pdf

Clavijo, A. (2004). Critical perspectives about bilingualism in the city of Bogota. Paper presented at primer simposio internacional sobre bilingüismo y 
educación bilingüe en Latinoamérica (Bilinglatam). Buenos Aires: Argentina. Retrieved from http://www. essarp.org.ar/bilinglatam/ingles/clavijo-olarte.html

Cubides, M., Florez, A., Guarín, A., Murcia, J., \& Janssen, G. (2011, Marhc). Bogota's streetside codeswitching and the resulting identities created. Presentation at the American Association of Applied Linguistics (AAAL) conference, Chicago, Illinois.

Davis, J. M. (2010). Using surveys for understanding and improving foreign language programs. Honolulu, HI: National Foreign Language Resource Center. Retrieved from the National Foreign Language Resource Center http://scholarspace.manoa.hawaii. edu/bitstream/handle/10125/14549/NW61-Davis. pdf? sequence $=10$

Dubin, F. \& Olshtain, E. (1986). Course design: Developing programs and materials for language learning. Cambridge, UK: Cambridge University Press.

Fernandez, D. \& Janssen, G. (2011, March). The longitudinal evolution of codeswitching within Facebook's private and public spaces. Presentation at the American Association of Applied Linguistics (AAAL) conference, Chicago, Illinois.

González, A. (2008). Bilingüismo en Colombia perspectivas globales y locales. Ministerio de Educación Nacional, Colombia. Retrieved from: http:// www.mineducacion.gov.co/observatorio/1722/ article-170864.html

González, A. (2009). On alternative and additional certifications in English language teaching: The case of Colombian EFL teachers' professional development. Íkala, 14(22), 183-209. Retrieved from http://aprendeenlinea.udea.edu.co/revistas/index. php/ikala/article/view/2638/2125

Hudson, T. (in press). Research design and analysis in Applied Linguistics (draft manuscript, cited with author's permission). University of Hawai'i: Honolulu, HI.

Iwai, T., Kondo, K., Lim, D.S.J., Ray, G.E., Shimizu, H., \& Brown, J.D. (1999). Japanese language needs analysis. Honolulu, HI: National Foreign Language Resource Center. Retrieved from the National Foreign Language Resource Center http://nflrc. hawaii.edu/NetWorks/NW13.pdf
Janssen, G., Ángel, C., \& Nausa, R. (2011). Informe de la investigación: El desarrollo de un currículo para la escritura de inglés nivel posgrado, según las necesidades y habilidades de los estudiantes (Proyecto IPD). Internal document. Universidad de los Andes.

López, A., \& Janssen, G. (2010). Validation study for Colombia's ECAES exam. Revista Lenguaje, 38(2), 423-448.

Messick, S. (1995). Validity of psychological assessment: Validation of inferences from persons' responses and performances as scientific inquiry into score meaning. American Psychologist, 50, 741-749.

Nunan, D. (1988). Syllabus design. Oxford, UK: Oxford University Press.

Ordoñez, C. (2011). Education for bilingualism: Connecting Spanish and English from the curriculum, into the classroom, and beyond. Profile, 13(2), 147-161.

Richards, J. C. (2001). Curriculum development in language teaching. Cambridge, UK: Cambridge University Press.

Truscott de Mejía, A. (2006). Bilingual Education in Colombia: Towards a recognition of Languages, cultures and identities. Colomb. Appli. Linguis. J., 8, 152-168.

Truscott de Mejía, A. M., Ordóñez, C. L., \& Fonseca, L. Universidad de los Andes, (2006). Estudio investigativo sobre el estado actual de la educación bilingüe (inglés-español) en Colombia. Retrieved from: http://cife.uniandes.edu.co/archivos/ Lineamientos_para_la_educacion_bilingue.pdf

Truscott de Mejía, A., López Mendoza, A., \& Peña Dix, B. (2011). Bilingüismo en el contexto colombiano: Iniciativas y perspectivas en el siglo XXI. Bogotá, Colombia: Ediciones Uniandes.

Universidad de los Andes. (2011, November). Programa de desarrollo integral: PDI 2011-2015. Retrieved from http://www.uniandes.edu.co/ images/stories/Descargables/pdi-2011-2015.pdf

Usma, J. (2009). Globalization and language and education reform in Colombia: A critical outlook. Íkala, Revista de Lenguaje y Cultura 14(20), 19-42. 


\section{Appendix A: Complete Questionnaire Results by Section}

Table 2. 2, 3. Descriptive statistics, informant biodata

\begin{tabular}{|c|c|c|c|c|c|c|c|c|c|}
\hline & Item & $n$ & M & SD & $\min$ & $\max$ & range & median & mode \\
\hline 2.1 & Age & 91 & 29.23 & 5.44 & 21 & 49 & 29 & 28 & 26 \\
\hline 3.5 & Year MA & 73 & 2009.56 & 2.97 & 1996 & 2012 & 17 & 2010 & 2011 \\
\hline 3.7 & Year BA & 80 & 2005.58 & 4.15 & 1988 & 2011 & 24 & 2006 & 2008 \\
\hline 3.9 & Publications & 86 & 3.35 & 3.65 & 0 & 16 & 17 & 2.5 & 1 \\
\hline 3.1 & Presentations & 88 & 4.76 & 6.04 & 0 & 40 & 41 & 3 & 2 \\
\hline 2.2 & Gender & 87 & \multicolumn{2}{|c|}{$\begin{array}{c}\text { female } \\
30(34.48 \%)\end{array}$} & \multicolumn{2}{|c|}{$\begin{array}{c}\text { male } \\
56(64.37 \%)\end{array}$} & \multicolumn{3}{|c|}{$\begin{array}{l}\text { declined to state } \\
1(1.15 \%)\end{array}$} \\
\hline \multirow[t]{2}{*}{2.4} & Marital status & 92 & \multicolumn{2}{|c|}{$\begin{array}{c}\text { single } \\
67(72.83 \%)\end{array}$} & \multicolumn{2}{|c|}{$\begin{array}{c}\text { separated } \\
2 \quad(2.17 \%)\end{array}$} & \multicolumn{2}{|c|}{$\begin{array}{c}\text { divorced } \\
2(2.17 \%)\end{array}$} & $\begin{array}{ll} & \text { total } \\
71 & (77.17 \%)\end{array}$ \\
\hline & & & \multicolumn{2}{|c|}{$\begin{array}{c}\text { domestic partner } \\
6 \quad(6.52 \%)\end{array}$} & \multicolumn{2}{|c|}{$\begin{array}{c}\text { married } \\
16(17.39 \%)\end{array}$} & & \multicolumn{2}{|c|}{$\begin{array}{c}\text { total } \\
22(23.91 \%) \\
\end{array}$} \\
\hline 2.5 & Children & 91 & \multicolumn{2}{|c|}{$\begin{array}{l}\text { no children = } \\
63(69.23 \%)\end{array}$} & \multicolumn{2}{|c|}{$\begin{array}{c}\text { children = } \\
28(30.77 \%)\end{array}$} & & & \\
\hline
\end{tabular}

Note. $\mathrm{N}=92$. These data come from questionnaire sections 2 and 3 , which asked informants to report basic personal and academic biodata, respectively. Items described in the results section have been shaded grey. Cronbach's alpha $=-0.025$.

Table 3 4. Descriptive statistics, time investments (hours per week)

\begin{tabular}{|c|c|c|c|c|c|c|c|c|c|}
\hline & Time investment & $n$ & M & SD & $\min$ & $\max$ & range & median & mode \\
\hline 4.1 & Work* & 91 & 24.96 & 18.37 & 0 & 100 & 101 & 20 & 20 \\
\hline 4.2 & In class* & 89 & 10.15 & 6.42 & 0 & 40 & 41 & 9 & 10 \\
\hline 4.3 & English, desirable & 91 & 5.98 & 4.58 & 0 & 20 & 21 & 4 & 4 \\
\hline 4.4 & English, realistic* & 88 & 3.76 & 3.34 & 0 & 13 & 14 & 3 & 0 \\
\hline 4.5 & Other homework* & 88 & 15.33 & 10.16 & 0 & 40 & 41 & 10 & 10 \\
\hline 4.6 & Family** & 83 & 12.07 & 11.32 & 0 & 40 & 41 & 10 & 0 \\
\hline 4.7 & Relatives ${ }^{* *}$ & 86 & 5.38 & 6.18 & 0 & 40 & 41 & 4 & 0 \\
\hline 4.8 & Sport** & 88 & 5.43 & 3.72 & 0 & 20 & 21 & 5 & 4 \\
\hline \multirow[t]{4}{*}{4.9} & Religion** & 87 & 1.33 & 2.14 & 0 & 12 & 13 & 0 & 0 \\
\hline & Work, study sum* & & 54.20 & & & & & & \\
\hline & Personal time sum ${ }^{\star \star}$ & & 24.21 & & & & & & \\
\hline & Sum & & 78.41 & & & & & & \\
\hline
\end{tabular}

Note. $\mathrm{N}=$ 92. Means are reported in terms of hours/ week. These data come from section 4, which asked informants to report the number of hours per week invested in various settings. Desirable time for English was not included in either calculation, as it represents a fictitious time use. Items described in the results section have been shaded grey.

*indicates work/ study time use. ${ }^{* \star}$ indicates personal time use. 
Table 4 5.1. Descriptive statistics, English use in different language domains, mean ranked

\begin{tabular}{|l|l|l|l|l|l|l|l|l|l|}
\hline & Language domain & $\mathrm{n}$ & $\mathrm{M}$ & $\mathrm{SD}$ & $\mathrm{min}$ & $\mathrm{max}$ & range & median & mode \\
\hline $5.1 \mathrm{H}$ & Reading-university & 90 & 4.51 & 0.91 & 1 & 5 & 5 & 5 & 5 \\
\hline $5.1 \mathrm{~J}$ & Reading-work & 90 & 4.07 & 1.27 & 1 & 5 & 5 & 5 & 5 \\
\hline $5.1 \mathrm{P}$ & Music & 91 & 4.00 & 1.05 & 1 & 5 & 5 & 4 & 5 \\
\hline $5.1 \mathrm{~N}$ & Movies & 91 & 3.86 & 1.12 & 1 & 5 & 5 & 4 & 5 \\
\hline 5.10 & TV & 91 & 3.43 & 1.28 & 1 & 5 & 5 & 4 & 4 \\
\hline $5.1 \mathrm{M}$ & Reading-fun & 91 & 3.12 & 1.26 & 1 & 5 & 5 & 3 & 3 \\
\hline $5.1 \mathrm{I}$ & Writing-university & 91 & 3.01 & 1.19 & 1 & 5 & 5 & 3 & 3 \\
\hline $5.1 \mathrm{~K}$ & Writing-work & 88 & 2.88 & 1.22 & 1 & 5 & 5 & 3 & 2 \\
\hline $5.1 \mathrm{~L}$ & Writing-friends & 91 & 2.38 & 1.09 & 1 & 5 & 5 & 2 & 3 \\
\hline $5.1 \mathrm{~F}$ & Speaking-work & 89 & 2.35 & 1.09 & 1 & 5 & 5 & 2 & 1 \\
\hline $5.1 \mathrm{G}$ & Speaking-friends & 91 & 1.84 & 0.96 & 1 & 5 & 5 & 2 & 1 \\
\hline $5.1 \mathrm{E}$ & Speaking-partner & 90 & 1.82 & 1.00 & 1 & 5 & 5 & 1 & 1 \\
\hline $5.1 \mathrm{Q}$ & Dreaming & 88 & 1.77 & 1.00 & 1 & 5 & 5 & 1 & 1 \\
\hline $5.1 \mathrm{C}$ & Speaking-siblings & 90 & 1.34 & 0.75 & 1 & 4 & 4 & 1 & 1 \\
\hline $5.1 \mathrm{D}$ & Speaking-relatives & 91 & 1.31 & 0.76 & 1 & 4 & 4 & 1 & 1 \\
\hline $5.1 \mathrm{~A}$ & Speaking to parents & 91 & 1.10 & 0.45 & 1 & 4 & 4 & 1 & 1 \\
\hline $5.1 \mathrm{~B}$ & Parents speaking to informant & 91 & 1.09 & 0.38 & 1 & 3 & 3 & 1 & 1 \\
\hline
\end{tabular}

Note. $\mathbf{N}=92$. Cronbach's alpha: 0.876 . These data have been organized in decreasing order of means. Question 5.1 of the 2011 questionnaire asked informants to report their frequency of English use within these different domains, with (5) indicating a high usage, (3) indicating a moderate usage, and (1) indicating a low usage. Cronbach's alpha for the 2011 and 2009 data together is 0.804 .

Table 5 5.3. Descriptive statistics, reported ability in different general English language skill areas, mean ranked

\begin{tabular}{|c|c|c|c|c|c|c|c|c|c|}
\hline & Skill area & $\mathrm{n}$ & $\mathrm{M}$ & $\mathrm{SD}$ & $\mathrm{min}$ & $\max$ & range & median & mode \\
\hline 5.3E & Reading & 88 & 4.23 & 0.99 & 1 & 5 & 5 & 5 & 5 \\
\hline 5.3C & Listening & 89 & 3.54 & 1.24 & 1 & 5 & 5 & 4 & 4 \\
\hline $5.3 \mathrm{G}$ & Vocabulary & 89 & 3.34 & 1.11 & 1 & 5 & 5 & 4 & 4 \\
\hline 5.3A & Grammar & 89 & 3.33 & 0.99 & 1 & 5 & 5 & 3 & 3 \\
\hline 5.3B & Writing & 89 & 3.06 & 1.10 & 1 & 5 & 5 & 3 & 3 \\
\hline 5.3F & Pronunciation & 89 & 2.96 & 1.11 & 1 & 5 & 5 & 3 & 3 \\
\hline 5.3D & Speaking & 88 & 2.85 & 1.02 & 1 & 5 & 5 & 3 & 3 \\
\hline
\end{tabular}

Note. Question 5.3 of the 2011 questionnaire asked informants to report their ability in different general English language skill areas, with (5) indicating a high level, (3) indicating a moderate level, and (1) indicating a low level. N=92. Internal consistency for this data was calculated using Cronbach's alpha: 0.914 . In contrast to table 6, this table has been organized from highest to lowest means, to demonstrate that level (table 5) and difficulty (table 6) are negatively correlated. 
Table 6.5.4. Descriptive statistics, reported difficulty in different general English language skill areas, increasing mean ranked

\begin{tabular}{|c|c|c|c|c|c|c|c|c|c|}
\hline$\S$ & Skill area & $\mathrm{n}$ & $\mathrm{M}$ & $\mathrm{SD}$ & $\min$ & $\max$ & range & median & mode \\
\hline $5.4 \mathrm{E}$ & Reading & 87 & 1.66 & 0.91 & 1 & 5 & 5 & 1 & 1 \\
\hline $5.4 \mathrm{C}$ & Listening & 87 & 2.52 & 1.30 & 1 & 5 & 5 & 2 & 1 \\
\hline $5.4 \mathrm{~A}$ & Grammar & 87 & 2.63 & 1.16 & 1 & 5 & 5 & 3 & 3 \\
\hline $5.4 \mathrm{G}$ & Vocabulary & 88 & 2.65 & 1.07 & 1 & 5 & 5 & 3 & 2 \\
\hline $5.4 \mathrm{~B}$ & Writing & 88 & 2.92 & 1.19 & 1 & 5 & 5 & 3 & 3 \\
\hline $5.4 \mathrm{~F}$ & Pronunciation & 88 & 2.94 & 1.20 & 1 & 5 & 5 & 3 & 2 \\
\hline $5.4 \mathrm{D}$ & Speaking & 88 & 3.24 & 1.27 & 1 & 5 & 5 & 3 & 3 \\
\hline
\end{tabular}

Note. Question $\mathbf{5 . 4}$ of the 2011 questionnaire asked informants to report the frequency of difficulties experienced in the different general English language skill areas, with (5) indicating a high frequency of difficulties, (3) indicating a moderate level, and (1) indicating a low level. $\mathrm{N}=92$. Cronbach's alpha 0.881 . In contrast to table 5 , this table has been organized from lowest to highest means, to demonstrate that level (table 5) and difficulty (table 6) are negatively correlated.

Table 76.1. Descriptive statistics, importance of different general English language skill areas in terms of being successful during a PhD program

\begin{tabular}{|c|c|c|c|c|c|c|c|c|c|}
\hline & Skill area & $\mathrm{n}$ & $\mathrm{M}$ & $\mathrm{SD}$ & $\min$ & $\max$ & range & median & mode \\
\hline $6.1 \mathrm{G}$ & Reading & 90 & 4.86 & 0.41 & 3 & 5 & 3 & 5 & 5 \\
\hline $6.1 \mathrm{~F}$ & Speaking INT & 90 & 4.73 & 0.51 & 3 & 5 & 3 & 5 & 5 \\
\hline $6.1 \mathrm{D}$ & Listening INT & 90 & 4.71 & 0.64 & 1 & 5 & 5 & 5 & 5 \\
\hline $6.1 \mathrm{~B}$ & Writing & 89 & 4.69 & 0.67 & 1 & 5 & 5 & 5 & 5 \\
\hline $6.1 \mathrm{~V}$ & Vocabulary & 89 & 4.48 & 0.74 & 2 & 5 & 4 & 5 & 5 \\
\hline $6.1 \mathrm{~A}$ & Grammar & 88 & 4.39 & 0.86 & 1 & 5 & 5 & 5 & 5 \\
\hline $6.1 \mathrm{H}$ & Pronunciation & 90 & 4.36 & 0.83 & 2 & 5 & 4 & 5 & 5 \\
\hline $6.1 \mathrm{C}$ & Listening COL & 90 & 4.11 & 1.04 & 1 & 5 & 5 & 4 & 5 \\
$6.1 \mathrm{E}$ & Speaking COL & 88 & 3.84 & 1.02 & 1 & 5 & 5 & 4 & 5 \\
\hline
\end{tabular}

Note. Question 6.1 of the 2011 questionnaire asked informants to report the importance of different general English language skill areas in terms of having success during a PhD program, with (5) indicating a high level of importance, (3) indicating a moderate level, and (1) indicating a low level. $\mathrm{N}=92$. Internal consistency for these data was calculated using Cronbach's alpha: 0.853 . COL indicates the use of this skill area in Colombia; INT indicates the use of this skill area in the international context.

Table 8 6.2. Descriptive statistics, importance of different general English language skill areas in terms of being successful after a PhD program, mean ranked

\begin{tabular}{|c|c|c|c|c|c|c|c|c|c|}
\hline$\S$ & Skill area & $\mathrm{n}$ & $\mathrm{M}$ & $\mathrm{SD}$ & $\min$ & $\max$ & range & median & mode \\
\hline $6.2 \mathrm{D}$ & Listening INT & 87 & 4.84 & 0.43 & 3 & 5 & 3 & 5 & 5 \\
\hline $6.2 \mathrm{G}$ & Reading & 86 & 4.84 & 0.43 & 3 & 5 & 3 & 5 & 5 \\
\hline $6.2 \mathrm{~F}$ & Speaking INT & 87 & 4.82 & 0.47 & 3 & 5 & 3 & 5 & 5 \\
\hline $6.2 \mathrm{~B}$ & Writing & 86 & 4.76 & 0.46 & 3 & 5 & 3 & 5 & 5 \\
\hline 6.21 & Vocabulary & 87 & 4.61 & 0.62 & 3 & 5 & 3 & 5 & 5 \\
\hline
\end{tabular}




\begin{tabular}{|l|c|c|c|c|c|c|c|c|c|}
\hline $6.2 \mathrm{~A}$ & Grammar & 86 & 4.49 & 0.75 & 2 & 5 & 4 & 5 & 5 \\
\hline $6.2 \mathrm{H}$ & Pronunciation & 87 & 4.48 & 0.78 & 2 & 5 & 4 & 5 & 5 \\
\hline $6.2 \mathrm{C}$ & Listening COL & 87 & 4.15 & 1.03 & 1 & 5 & 5 & 5 & 5 \\
\hline $6.2 \mathrm{E}$ & Speaking COL & 86 & 4.09 & 0.99 & 1 & 5 & 5 & 4 & 5 \\
\hline
\end{tabular}

Note. Question 6.2 of the 2011 questionnaire asked informants to report the importance of different English language abilities in terms of having success after a PhD program, with (5) indicating a high level of importance, (3) indicating a moderate level, and (1) indicating a low level. $\mathbf{N}=\mathbf{9 2}$. Internal consistency for these data was calculated using Cronbach's alpha: 0.879 . COL indicates the use of this skill area in Colombia; INT indicates the use of this skill area in the international context.

Table 9 7. Descriptive statistics, importance of different Programa IPD speaking sub-skills, mean ranked

\begin{tabular}{|c|c|c|c|c|c|c|c|c|c|}
\hline & Speaking sub-skills & $n$ & M & SD & $\min$ & $\max$ & range & median & mode \\
\hline $7.1 \mathrm{H}$ & Fluency INT & 90 & 4.81 & 0.56 & 1 & 5 & 5 & 5 & 5 \\
\hline 7.10 & Presentations INT & 88 & 4.80 & 0.57 & 1 & 5 & 5 & 5 & 5 \\
\hline $7.1 \mathrm{~N}$ & Discussion participa. INT & 90 & 4.79 & 0.59 & 1 & 5 & 5 & 5 & 5 \\
\hline $7.1 \mathrm{R}$ & Communicating ideas INT & 90 & 4.79 & 0.57 & 1 & 5 & 5 & 5 & 5 \\
\hline $7.1 \mathrm{~T}$ & Participate projects INT & 89 & 4.79 & 0.57 & 1 & 5 & 5 & 5 & 5 \\
\hline $7.1 \mathrm{~L}$ & Discussion start INT & 89 & 4.76 & 0.64 & 1 & 5 & 5 & 5 & 5 \\
\hline $7.1 X$ & Host visitor INT & 89 & 4.76 & 0.67 & 1 & 5 & 5 & 5 & 5 \\
\hline $7.1 \mathrm{~V}$ & Socialize w/ peers INT & 90 & 4.76 & 0.59 & 1 & 5 & 5 & 5 & 5 \\
\hline 7.1J & Pronunciation INT & 90 & 4.74 & 0.63 & 1 & 5 & 5 & 5 & 5 \\
\hline $7.1 \mathrm{~F}$ & Word precision INT & 90 & 4.73 & 0.75 & 1 & 5 & 5 & 5 & 5 \\
\hline 7.1P & Lead discussion INT & 90 & 4.71 & 0.62 & 1 & 5 & 5 & 5 & 5 \\
\hline $7.1 \mathrm{~W}$ & Host visitor COL & 89 & 4.69 & 0.70 & 1 & 5 & 5 & 5 & 5 \\
\hline $7.1 \mathrm{~S}$ & Participate projects COL & 90 & 4.39 & 0.86 & 1 & 5 & 5 & 5 & 5 \\
\hline $7.1 \mathrm{M}$ & Discussion participa. COL & 90 & 4.38 & 0.84 & 1 & 5 & 5 & 5 & 5 \\
\hline $7.1 \mathrm{E}$ & Word precision COL & 90 & 4.32 & 0.98 & 1 & 5 & 5 & 5 & 5 \\
\hline 7.11 & Pronunciation COL & 90 & 4.32 & 0.96 & 1 & 5 & 5 & 5 & 5 \\
\hline 7.10 & Lead discussion COL & 90 & 4.27 & 0.96 & 1 & 5 & 5 & 5 & 5 \\
\hline $7.1 \mathrm{~K}$ & Discussion start COL & 89 & 4.26 & 0.95 & 1 & 5 & 5 & 5 & 5 \\
\hline $7.1 Q$ & Communicating ideas COL & 90 & 4.23 & 1.05 & 1 & 5 & 5 & 5 & 5 \\
\hline $7.1 \mathrm{G}$ & Fluency COL & 90 & 4.17 & 1.04 & 1 & 5 & 5 & 4 & 5 \\
\hline $7.1 \mathrm{U}$ & Socialize w/ peers COL & 90 & 4.04 & 1.07 & 1 & 5 & 5 & 4 & 5 \\
\hline $7.1 \mathrm{C}$ & Presentations COL & 90 & 3.86 & 1.24 & 1 & 5 & 5 & 4 & 5 \\
\hline $7.1 \mathrm{~B}$ & Poetry INT & 87 & 2.52 & 1.40 & 1 & 5 & 5 & 2 & 1 \\
\hline $7.1 \mathrm{~A}$ & Poetry COL & 89 & 1.92 & 1.14 & 1 & 5 & 5 & 2 & 1 \\
\hline
\end{tabular}

Note. $\mathbf{N}=92$. In Question 7.1 of the 2011 questionnaire, informants rated the importance of different Programa IPD speaking sub-skills for both the national (COL) and international (INT) contexts. Cronbach's alpha: 0.947. 
Table 10 8. Descriptive statistics, importance of different Programa IPD listening sub-skills, mean ranked

\begin{tabular}{|l|l|l|l|l|l|l|l|l|l|}
\hline & Listening sub-skills & $\mathrm{N}$ & $\mathrm{M}$ & $\mathrm{SD}$ & $\min$ & $\max$ & range & median & mode \\
\hline $8.1 \mathrm{~F}$ & Understand instructions INT & 89 & 4.84 & 0.52 & 2 & 5 & 4 & 5 & 5 \\
\hline $8.1 \mathrm{~J}$ & Understand main ideas INT & 89 & 4.83 & 0.53 & 2 & 5 & 4 & 5 & 5 \\
\hline $8.1 \mathrm{~B}$ & Understand presentations INT & 88 & 4.82 & 0.54 & 2 & 5 & 4 & 5 & 5 \\
\hline $8.1 \mathrm{P}$ & Understand discussions INT & 89 & 4.80 & 0.62 & 1 & 5 & 5 & 5 & 5 \\
\hline $8.1 \mathrm{~L}$ & Understand different speech paces INT & 88 & 4.80 & 0.63 & 1 & 5 & 5 & 5 & 5 \\
\hline $8.1 \mathrm{H}$ & Understand informal language INT & 89 & 4.78 & 0.56 & 2 & 5 & 4 & 5 & 5 \\
\hline $8.1 \mathrm{~N}$ & Understand different accents INT & 89 & 4.71 & 0.73 & 1 & 5 & 5 & 5 & 5 \\
\hline $8.1 \mathrm{~A}$ & Understand presentations COL & 89 & 4.70 & 0.61 & 2 & 5 & 4 & 5 & 5 \\
\hline $8.1 \mathrm{D}$ & Taking notes INT & 89 & 4.70 & 0.63 & 2 & 5 & 4 & 5 & 5 \\
\hline $8.1 \mathrm{I}$ & Understand main ideas COL & 89 & 4.64 & 0.64 & 2 & 5 & 4 & 5 & 5 \\
\hline $8.1 \mathrm{E}$ & Understand instructions COL & 89 & 4.57 & 0.85 & 1 & 5 & 5 & 5 & 5 \\
\hline $8.1 \mathrm{~A}$ & Understand discussions COL & 89 & 4.51 & 0.85 & 1 & 5 & 5 & 5 & 5 \\
\hline $8.1 \mathrm{~K}$ & Understand different speech paces COL & 89 & 4.47 & 0.87 & 1 & 5 & 5 & 5 & 5 \\
\hline $8.1 \mathrm{C}$ & Taking notes COL & 89 & 4.40 & & 1 & 5 & 5 & 5 & 5 \\
\hline $8.1 \mathrm{G}$ & Understand informal language COL & 89 & 4.33 & 1.01 & 1 & 5 & 5 & 5 & 5 \\
\hline $8.1 \mathrm{M}$ & Understand different accents COL & 89 & 4.21 & 1.07 & 1 & 5 & 5 & 5 & 5 \\
\hline
\end{tabular}

Note. In question 8.1 of the 2011 questionnaire, informants rated the importance of different Programa IPD listening sub-skills for the national (COL) and international (INT) contexts. N=92. Cronbach's alpha: 0.961.

Table 11 9. Descriptive statistics, importance of different Programa IPD writing subskills, mean ranked

\begin{tabular}{|l|l|l|l|l|l|l|l|l|l|}
\hline & Writing sub-skills & $\mathrm{n}$ & $\mathrm{M}$ & $\mathrm{SD}$ & $\min$ & $\max$ & range & median & mode \\
\hline $9.1 \mathrm{~J}$ & Articles in scholarly journals & 87 & 4.84 & 0.57 & 1 & 5 & 5 & 5 & 5 \\
\hline $9.1 \mathrm{D}$ & Results sections & 87 & 4.80 & 0.61 & 1 & 5 & 5 & 5 & 5 \\
\hline $9.1 \mathrm{Q}$ & Idea development & 83 & 4.80 & 0.60 & 1 & 5 & 5 & 5 & 5 \\
\hline $9.1 \mathrm{~V}$ & Idea coherence & 83 & 4.76 & 0.67 & 1 & 5 & 5 & 5 & 5 \\
\hline $9.1 \mathrm{H}$ & Argument structure & 87 & 4.75 & 0.61 & 1 & 5 & 5 & 5 & 5 \\
\hline $9.1 \mathrm{~W}$ & Information synthesis & 83 & 4.75 & 0.66 & 1 & 5 & 5 & 5 & 5 \\
\hline 9.10 & Paragraph organization & 83 & 4.73 & 0.66 & 1 & 5 & 5 & 5 & 5 \\
\hline $9.1 \mathrm{P}$ & Text organization & 83 & 4.73 & 0.68 & 1 & 5 & 5 & 5 & 5 \\
\hline $9.1 \mathrm{E}$ & Concision & 86 & 4.73 & 0.69 & 1 & 5 & 5 & 5 & 5 \\
\hline $9.1 \mathrm{~N}$ & Vocabulary & 84 & 4.73 & 0.63 & 1 & 5 & 5 & 5 & 5 \\
\hline $9.1 \mathrm{~B}$ & Introduction sections & 86 & 4.72 & 0.66 & 1 & 5 & 5 & 5 & 5 \\
\hline $9.1 \mathrm{~S}$ & Editing & 83 & 4.71 & 0.72 & 1 & 5 & 5 & 5 & 5 \\
\hline $9.1 \mathrm{M}$ & Sentence structure & 84 & 4.70 & 0.65 & 1 & 5 & 5 & 5 & 5 \\
\hline $9.1 \mathrm{R}$ & Tone & 83 & 4.69 & 0.70 & 1 & 5 & 5 & 5 & 5 \\
\hline $9.1 \mathrm{C}$ & Methods sections & 86 & 4.67 & 0.73 & 1 & 5 & 5 & 5 & 5 \\
\hline
\end{tabular}




\begin{tabular}{|c|c|c|c|c|c|c|c|c|c|}
\hline 9.11 & Cause-effect & 86 & 4.67 & 0.68 & 1 & 5 & 5 & 5 & 5 \\
\hline $9.1 \mathrm{U}$ & Citations & 83 & 4.65 & 0.77 & 1 & 5 & 5 & 5 & 5 \\
\hline $9.1 \mathrm{~F}$ & Compare-contrast & 86 & 4.64 & 0.70 & 1 & 5 & 5 & 5 & 5 \\
\hline $9.1 X$ & Information critique & 83 & 4.64 & 0.77 & 1 & 5 & 5 & 5 & 5 \\
\hline $9.1 \mathrm{~L}$ & Punctuation & 85 & 4.64 & 0.70 & 1 & 5 & 5 & 5 & 5 \\
\hline 9.12 & Emails & 82 & 4.56 & 0.80 & 1 & 5 & 5 & 5 & 5 \\
\hline $9.1 Y$ & Taking notes & 83 & 4.53 & 0.85 & 1 & 5 & 5 & 5 & 5 \\
\hline $9.1 \mathrm{G}$ & Narratives & 87 & 4.38 & 0.96 & 1 & 5 & 5 & 5 & 5 \\
\hline $9.1 \mathrm{~K}$ & Creative writing & 86 & 4.24 & 1.01 & 1 & 5 & 5 & 5 & 5 \\
\hline $9.1 \mathrm{~A}$ & Literature reviews & 87 & 4.23 & 1.06 & 1 & 5 & 5 & 5 & 5 \\
\hline $9.1 \mathrm{~T}$ & Journalistic articles & 83 & 4.04 & 1.27 & 1 & 5 & 5 & 5 & 5 \\
\hline
\end{tabular}

Note. In question 9.1 of the 2011 questionnaire, informants rated the importance of different Programa IPD writing subskills. N=92. Internal consistency was calculated using Cronbach's alpha: 0.976.

Table 12 10. Descriptive statistics, importance of different Programa IPD reading subskills, mean ranked

\begin{tabular}{|c|c|c|c|c|c|c|c|c|c|}
\hline$\S$ & Reading subskills & $\mathrm{n}$ & $\mathrm{M}$ & $\mathrm{SD}$ & $\min$ & $\max$ & range & median & mode \\
\hline $10.1 \mathrm{~A}$ & Understanding publications & 83 & 4.87 & 0.44 & 3 & 5 & 3 & 5 & 5 \\
\hline $10.1 \mathrm{G}$ & Reading to memorize & 82 & 4.78 & 0.50 & 3 & 5 & 3 & 5 & 5 \\
\hline $10.1 \mathrm{H}$ & Scanning & 83 & 4.71 & 0.53 & 3 & 5 & 3 & 5 & 5 \\
\hline 10.10 & Finding information on the internet & 83 & 4.71 & 0.62 & 3 & 5 & 3 & 5 & 5 \\
\hline $10.1 \mathrm{~F}$ & Skimming & 83 & 4.66 & 0.59 & 3 & 5 & 3 & 5 & 5 \\
\hline $10.1 \mathrm{~L}$ & Responding critically to a reading & 83 & 4.66 & 0.61 & 3 & 5 & 3 & 5 & 5 \\
\hline $10.1 \mathrm{~J}$ & Understanding a text's organization & 83 & 4.65 & 0.61 & 3 & 5 & 3 & 5 & 5 \\
\hline $10.1 \mathrm{P}$ & Understanding author point of view & 83 & 4.64 & 0.67 & 2 & 5 & 4 & 5 & 5 \\
\hline $10.1 \mathrm{E}$ & Understanding main ideas & 83 & 4.63 & 0.73 & 1 & 5 & 5 & 5 & 5 \\
\hline $10.1 \mathrm{I}$ & Understanding unknown vocabulary & 83 & 4.63 & 0.64 & 3 & 5 & 3 & 5 & 5 \\
\hline $10.1 \mathrm{~N}$ & Finding information in a library & 83 & 4.63 & 0.66 & 3 & 5 & 3 & 5 & 5 \\
\hline $10.1 \mathrm{M}$ & Understanding author's tone & 83 & 4.60 & 0.66 & 3 & 5 & 3 & 5 & 5 \\
\hline $10.1 \mathrm{~K}$ & Reading pace & 83 & 4.55 & 0.72 & 2 & 5 & 4 & 5 & 5 \\
\hline $10.1 \mathrm{D}$ & Understanding reports & 83 & 4.52 & 0.80 & 1 & 5 & 5 & 5 & 5 \\
\hline $10.1 \mathrm{C}$ & Understanding news items & 83 & 3.95 & 1.05 & 1 & 5 & 5 & 4 & 5 \\
$10.1 \mathrm{~B}$ & Reading fiction & 82 & 3.71 & 1.22 & 1 & 5 & 5 & 4 & 5 \\
\hline
\end{tabular}

Note. In question $\mathbf{1 0 . 1}$ of the 2011 questionnaire, informants rated the importance of different Programa IPD reading subskills. N=92. Internal consistency was calculated using Cronbach's alpha: 0.949. 
Table 13 11. Descriptive statistics, importance of different Programa IPD lexico-grammatical subskills, mean ranked

\begin{tabular}{|l|l|l|l|l|l|l|l|l|l|}
\hline$\S$ & Skills & & & & & & & & \\
$11.1 \mathrm{~A}$ & Academic vocabulary & $n$ & $\mathbf{S} D$ & $\min$ & max & range & median & mode \\
\hline $11.1 \mathrm{E}$ & Functional gramar & 84 & 4.82 & 0.58 & 1 & 5 & 5 & 5 & 5 \\
\hline $11.1 \mathrm{D}$ & Grammatical precisión & 84 & 4.69 & 0.68 & 1 & 5 & 5 & 5 & 5 \\
\hline $11.1 \mathrm{C}$ & Grammatical terminology & 83 & 4.63 & 0.71 & 1 & 5 & 5 & 5 & 5 \\
\hline $11.1 \mathrm{~B}$ & Informal vocabulary & 84 & 4.56 & 0.77 & 1 & 5 & 5 & 5 & 5 \\
\hline
\end{tabular}

Note. In question $\mathbf{1 1 . 1}$ of the 2011 questionnaire, informants rated the importance of different Programa IPD lexico-grammatical SLOS. N=92. Internal consistency was calculated using Cronbach's alpha: 0.909.

\section{Appendix B: Cronbach's Alpha}

Table 14. Cronbach's alpha by questionnaire section

\begin{tabular}{|l|l|l|}
\hline$\S$ & Questionnaire construct & \\
\hline All & Statistical data for entire questionnaire & 0.116 \\
\hline$\S 2, \S 3$ & Biodata & -0.025 \\
\hline$\S 4$ & Time uses & 0.438 \\
\hline$\S 5.1$ & Historical language use in different domains & 0.876 \\
\hline$\S 5.3$ & Reported skill level, different general English language abilities & 0.914 \\
\hline$\S 5.4$ & Difficulty, different general English language abilities & 0.881 \\
\hline$\S 6.1$ & Relevance, different general English language abilities, success during PhD & 0.853 \\
\hline$\S 6.2$ & Relevance, different general English language abilities, success after PhD & 0.879 \\
\hline$\S 7$ & Programa IPD speaking sub-skills & 0.947 \\
\hline$\S 8$ & Programa IPD listening sub-skills & 0.961 \\
\hline$\S 9$ & Programa IPD writing sub-skills & 0.976 \\
\hline$\S 10$ & Programa IPD reading sub-skills & 0.949 \\
\hline$\S 11$ & Programa IPD vocabulary and grammar sub-skills & 0.909 \\
\hline
\end{tabular}

Note. The high values for each sub-section demonstrate very high internal consistency. Low alpha values are expected in for the whole questionnaire, which evaluates many different constructs, as does the sections 2, 3, and 4 that report biodata and time use.

\section{Endnotes}

1 Facilitar la internacionalización de los programas."

2 "Promover la movilidad efectiva de profesores en los ámbitos regional e internacional."

3 "4.3 Promover el desarrollo de investigaciones conjuntas con pares de universidades reconocidas internacionalmente."
4 "Mantener una activa presencia nacional e internacional mediante publicaciones, seminarios y eventos que promuevan la crítica y el debate en temas de interés público."

5 Project English for Doctorate Students

6 English for Doctorate Students Program 
7 In this paper, theoretical constructs will be italicized to separate these ideas from surrounding text. Questionnaire constructs, though written originally in Spanish, will be presented in English without a translation gloss, this for the sake of brevity

8 It is important to note that this survey research project was mixed methods in its approach, gathering both quantitative and qualitative data from a variety of sources; however, it is beyond the scope of this particular paper to report on anything beyond the quantitative results.
9 There were also 18 spaces where informants could provide extra information; these have not been included in the item count as they were not a different construct.

10 Logic flaws in this questionnaire were related to double- and triple-barreled questions, e.g. "Have you published articles and given conference presentations in English before?"

11 Prestige questions give to or take away from an informant's social status, e.g. "do you agree, as all wise people will, that learning a second language is essential in today's globalizing world?"

\section{THE AUTHORS}

GERRIET JANSSEN is currently working on his PhD in Second Language Studies at the University of Hawai'i in Manoa. Working in the general area of curriculum development and evaluation, he has conducted preliminary dissertation research on building evaluation systems as an part of language program development. Complementary areas of interest include sociolinguistics themes such as linguistic landscapes, language varieties, and endangered languages, and pedagogical themes such as the development of academic writing and presentation skills.

RICARDO NAUSA holds a B.A. in Philology and Languages (Universidad Nacional), and a M.A. in Applied Linguistics to TEFL (Universidad Distrital). He is currently a teaching English for Acedemic Purposes at Universidad de los Andes where he is also the coordinator of the English for Doctoral Students Program (IPD: Programa de Inglés para Doctorados). His interests include the teaching of academic writing and oral presentation skills, conversation analysis, CALL, and learning strategies.

CARLOS RICO finished his MA thesis on vocabulary learning and complexity theory (Rijksuniversiteit Groningen), and then returned to his native city of Bogotá to teach English for Language Majors and English for PhD Students (Inglés para Doctorados) at Universidad de Ios Andes for three years, collaborating with research being done there on curriculum development for advanced English language learners. Currently, Carlos is teaching Spanish in Germany while preparing to enter a PhD program in the field of Applied Linguistics. 